African Crop Science Journal by African Crop Science Society is licensed under a Creative Commons Attribution 3.0 Uganda License. Based on a work at www.ajol.info/ and www.bioline.org.br/cs DOI: http://dx.doi.org/10.4314/acsj.v26i1.1

\title{
WESTERN HONEY BEE MANAGEMENT FOR CROP POLLINATION
}

\author{
C.H. TONI ${ }^{1}$, B.A. DJOSSA ${ }^{1,2}$, H. YÉDOMONHAN ${ }^{3}$, E.T. ZANNOU ${ }^{4}$ and G.A. MENSAH ${ }^{5}$ \\ ${ }^{1}$ Laboratoire d'Ecologie Appliquée, Faculté des Sciences Agronomiques, Université d'Abomey-Calavi, Bénin \\ ${ }^{2}$ Ecole de Foresterie et Ingénierie du Bois, Université Nationale d'Agriculture, Benin \\ ${ }^{3}$ Faculté des Sciences et Techniques, Université d'Abomey-Calavi, Bénin \\ ${ }^{4}$ Laboratoire d'Entomologie Agricole, Faculté des Sciences Agronomiques, Université d'Abomey-Calavi, \\ Bénin \\ ${ }^{5}$ Centre de Recherche Agronomique d'Agonkanmey, Institut National de Recherches Agricoles du Bénin
}

Corresponding author: tonihermann9@gmail.com

(Received 11 September, 2017; accepted 9 February, 2018)

\begin{abstract}
This literature review seeks to provide an outlook of the use of Western honeybee for crop pollination around the world. It was prepared by collecting information on the use of managed honey bees, Apis mellifera in crop pollination from different sources. To address pollination deficits, farmers around the world contract with beekeepers that provide colonies of Western honey, Apis mellifera, in order to perform crop pollination. Some farmers pay for the bee colonies they host in their farms; while others obtain them for free. Apis mellifera is widely used for pollination purposes for several reasons, including its polylectic nature, its wide distribution, its relatively ease and low cost management, and hive products from which the beekeeper get additional incomes. The Western honey bee is used to pollinate 66 commodities on all continents, except Antarctica. A controlled use of Western honey bee for pollination services is reported mainly in developed countries. Because of the low application of this technology in Africa, research must be conducted in order to access the need of pollination service and then the profitability of this technology in the current African entomological fauna context. Despite its benefits, the use of managed Western honey bees can affect native pollinators and contribute to the spread of diseases, parasites and weeds.
\end{abstract}

Key Words: Apis mellifera, bee colonies, pollination deficit, pollination services

\section{RÉSUMÉ}

Cette synthèse bibliographique a pour objectif de faire le point de l'utilisation des colonies d'abeilles mellifères Apis mellifera pour assurer la pollinisation des cultures à travers le monde. Différentes sources bibliographiques sur l'utilisation de l'abeille mellifère ont été utilisées. Il ressort que pour résoudre le problème de déficit de pollinisation, les producteurs à travers le monde contractent avec les apiculteurs pour bénéficier des services de pollinisation de leurs colonies d'abeilles. Certains producteurs payent les apiculteurs pour le service rendu, tandis que d'autres l'obtiennent gratuitement. Apis mellifera est largement utilisé pour assurer la pollinisation des cultures pour plusieurs raisons à savoir le fait que l'abeille butinent plusieurs plantes, sa large distribution dans le monde, la relative facilité à élever l'espèce et les revenus additionnels générés par les produits de la ruche. L'abeille mellifère est utilisée pour assurer la pollinisation de 66 cultures sur tous les continents excepté l'Antarctique. Ce recours aux colonies à des fins de pollinisation a été essentiellement rapporté dans les pays développés. Compte tenu du faible recours aux colonies d'abeilles en Afrique, des études devraient s'intéresser 
aux besoins des services de pollinisation ainsi que la rentabilité d'une telle technique dans le contexte écologique africain. L'utilisation des colonies d'abeilles a aussi des effets néfastes tels que la dissémination des parasites et des adventices.

Mots Clés: Apis mellifera, colonies d'abeilles, déficit de pollinisation, services de pollinisation

\section{INTRODUCTION}

Biotic pollination is a crucial service in the reproduction process of flowering plants. About $75 \%$ of the world's crops benefit from biotic pollination (Klein et al., 2007). Insects in general, and mainly bees, are the most important pollinators; and contribute to pollination of $90 \%$ of 250000 angiosperm species recognised worldwide (Pouvreau, 2004), including 15-30\% of food production from plants (McGregor,1976).Pollinators improve the quality, quantity and commercial value of crops (Sabbahi et al., 2005; Klatt et al., 2014). These important ecosystem services are provided by wild and managed pollinators (Velthuis and Doorn, 2006; Blitzer et al., 2016).

Before the development of intensive agriculture, wild and native insect pollinators provided sufficient pollination to crops (Batra, 1995; Mishra, 1995). However, to increase yields and food production, intensive agricultural practices, including the destruction of natural ecosystems to set large agricultural fields, and the use of pesticides and fertilisers, were adopted by farmers in many countries. These agricultural practices are not without negative consequences on natural pollinators. First, large agricultural fields surely fragment and disturb natural habitats on which pollinators rely for mating, foraging and nesting (Kleijn and Raemakers, 2008; Bailey et al., 2014). Large monoculture farms also reduce insect pollinators in surrounding fields (du Toit, 1988). Second, the use of pesticides reduce bee species richness and abundance in farms (Kovács-Hostyánszki et al., 2011). Pesticides can harm pollinators by direct intoxication during sprays (Pilatic, 2012); and indirect intoxication via indirect contacts with treated plants, or accumulating in nectar and pollen that affect pollinator performance and behaviour afterwards (Laurino et al., 2011; Cresswell, 2011). Besides, herbicides can affect pollinators indirectly by decreasing floral resource availability (Potts et al., 2010). Other factors such as climate change (Rader et al., 2013), diseases and parasites (Potts et al., 2010) have also been cited as causes of wild bee decline.

Given the importance of pollinators in crop production, decline of wild pollinator populations and diversity has resulted in decline of crop yields in many parts of the world (Garibaldi et al., 2011; Partap and Ya, 2012). To face the pollination deficit problems, different alternatives to ensure crop pollination have been developed. Some farmers such as vanilla growers in Uganda, passion fruit growers in Brazil and apple growers in Sichuan-China pollinate their crops by hand (Klein et al., 2007; FAO, 2008; Partap and Ya, 2012). This pollination method is difficult and expensive (Partap, 1999; Garibaldi et al., 2012).

Tomato growers use hand-held electrical shakers mainly in greenhouses, a method that is also expensive and can damage flowers (Bispo et al., 2009). In other cases, farmers use pollen sprays (Bahadur et al., 2015), but the majority of farmers have recourse to managed bees to ensure crop pollination. The bees used include leaf cutter bees (Megachile rotundata), alkali bees (Nomia melanderi), several mason bee species (Osmia spp.), the gray-haired alfalfa bee (Rhophitoides canus), several bumble bees (Bombus spp.), several species of stingless bees and honey bees (Apis spp.) (Bosch and Kemp, 2001; Goodwin, 2012).

Among bee species used for crop pollination, the Western or European honey bee (Apis mellifera L.) is by far the most commonly used species (Klein et al., 2007) 
and the most efficient due to the size of its colonies, its foraging organisation and habits. Nowadays, millions of hives of Apis mellifera are used by farmers and beekeepers for pollination of several crops and fruits around the world.

Several research documents highlight the use of Western honeybee in some regions or countries of the world (Partap, 1999; Goodwin, 2012; Paudel et al., 2015). This literature review seeks to provide an outlook of the use of Western honeybee for crop pollination around the world. Here, we reviewed reasons of the wide use of Apis mellifera for providing pollination services, the current state of Western honey bee colonies use in crop pollination, crops in which growers use the species and finally limitations and challenges of honey bee colonies using for crop pollination.

\section{METHODOLOGY}

This paper was prepared by collecting information on the use of managed honey bees Apis mellifera in crop pollination around the world. Information were collected from various sources including scientific articles, books, proceedings papers, extension leaflets and publications, thesis dissertations, reports, magazines, and personal communication. Crops in which Apis mellifera colonies are used for pollination were searched on the web (see supplementary material) and sorted into six groups based on 40 CFR 180.41 - crop group tables (table established with the crop grouping regulation and published in the Federal Register of US in 1995). Countries where honey bee colonies are used for pollination purpose were classified per continent.

\section{RESULTS AND DISCUSSION}

Scope for Western honey bee for pollination. Several bee species are managed for crop pollination worldwide. However, the Western or European honey bee Apis mellifera is currently the most used species for pollination purposes for several reasons (Klein et al., 2007). Apis mellifera is a polylectic species that forages on a wide variety of plant species (Cane and Sipes, 2006). By collecting nectar and pollen on several flowers, the Western honey bee contributes to pollination of number of crops (Klein et al., 2007; Le Conte and Navajas, 2008). This bee species is quite easy to manage and the management practices are well established and documented in many regions of the world (Benecke, 2007; Bradbear, 2010; Kumar, 2012). Rapid development of beekeeping industry in the $19^{\text {th }}$ century eases keeping honey bee colonies in man-made movable hives, which can be transported easily to fields and orchards for pollination (Anderson et al., 1983; Partap, 1999). Moreover, Apis mellifera colonies have sufficient number of bees (40,000-70,000 individuals per colony), to perform efficiently crop pollination (Sammataro and Avitabile, 1988, Stanghellini et al., 1998).

Economic reasons also motivate the wide use of A. mellifera. Besides, pollination services, A. mellifera is managed for hive products mainly the honey. In USA, the second source of revenues of beekeepers, after pollination services, is the sale of honey (Champetier, 2010). Comparing the honey production, the Western honey bee, $A$. Mellifera, is 2 - 10 times more productive than the Asian honey bee (Apis cerana), which is managed for crop pollination in some Asian countries (Partap, 2003). This comparative advantage has led to increased use of $A$. mellifera for commercial honey production and pollination services across Asia (Tsutsumi and Oishi, 2010; Koetz, 2013). Moreover, the Western honey bee is cheaper than other managed pollinators, such as bumble bees (Mann, 2015). According to Partap (2003), the use of $A$. mellifera is the most costeffective method for pollinating fruit crops. Nests of this species are perennial and beekeepers or growers do not need to buy another colony every year, even if they can 
replace existing queens about every two years, to avoid a decrease of the colony performance (Tsutsumi and Oishi, 2010).

Finally, the use of A. Mellifera is favoured by the occurrence of the species on several continents (Africa and Europe) and its successful introduction to Asia, Australia and the Americas (Bradbear, 2010), covering then almost the whole world; even though it shows some intra-species variability within and between regions. Thus, the species has 25 subspecies distributed and adapted to different regions across the globe (Miguel et al., 2007).

History and current status of honey bee colonies use for crop pollination. The use of managed honey bee, Apis mellifera, for crop pollination likely started in 1895 in Virginia (USA), where bee colonies were rented to pollinate pears (Waite, 1895). Later in 1909 , the species was rented for pollination of apples in New Jersey (Weber, 2012). The use of honey bee colonies for crop pollination is done by placing bee hives in or near fields to ensure a good pollination of a focal crop. Nowadays, this practice is developed and well organised in some countries such as USA, Canada, Australia and New-Zealand, Honey bee hives used for crop pollination can be obtained in three different ways, namely $(i)$ hives owned by growers (Goodwin, 2012; Plant Health Australia, 2013), (ii) hives placed for free because a beekeeper wants to harvest honey from the site (Rucker et al., 2012), and (iii) hives hired from a commercial beekeeper or government institutions (Partap, 1998; Morse and Calderone, 2000).

In the first case, growers must have beekeeping skills to maintain large numbers of robust hives year-round; or engage a beekeeper to manage the colonies (Goodwin, 2012). In the second case, growers have little control on bee colonies introduced and infected managed bees could spread infections to wild pollinators of their farms (Goodwin, 2012). Hiring bee hives is the most common method used by growers to obtain bee colonies.
Managed bees are usually hired by growers from private beekeepers or companies and in some cases from government institutions in Europe, America, South Africa and Asia. In some countries such as USA and Australia, where bee colonies use is well developed, there are beekeepers for which the main objective is providing pollination services. They move their hives from farm to farm over long distances, throughout the year; and this activity constitutes the major source of incomes for them (Burgett, 1999). In recent years, the pollination service provided by managed honey bees alone was estimated to $\$ 14.6$ billion in the United States (Bauer and Wing, 2010).

In Africa, the use of managed honeybee has been reported only in Tunisia and South Africa (Barbouche, 2009; Allsopp, 2005; Melin et al., 2014). However, this practice has been reported in some scientific experiments in Democratic Republic of Congo with the African melon, Cucumeropsis mannii (Ndola, 2015), in Benin and Ghana with the cashew, Anacardium occidentale (Aidoo et al., 2015) in order to assess its effect on crop yield and farmers income.

To rent managed bee colonies, beekeepers generally contract with growers (Melhim et al., 2010), even if for some of them a written pollination contract is not necessary (Sagili and Burgett, 2011). A pollination contract specifies mutual responsibilities of beekeepers and growers (Dupree et al., 1995; Melhim et al., 2010; Sagili and Burgett, 2011), as it generally provides information on:

(i) names and addresses of the contracting parties;

(ii) timing of colonies' delivery and removal; (iii) the pollinated crop and its location;

(iv) number of colonies hired and their strength (number of frames of brood and bees);

(v) pattern of colony placement throughout the crop;

(vi) right of access and entry for beekeeper for colony maintenance;

(vii) rental fee and terms of payment; 
(viii) advance notice to the beekeeper if pesticides are to be applied and rules of pesticide use;

(ix) special management practices;

(x) compensation to both parties for any additional unspecified tasks, damages, and violations.

Contracts are usually signed early to blooming period so that beekeepers have time to prepare colonies.

Rental fees and managed hive density vary according to the crop to be pollinated. In general, fees for pollination of non-honey crops (apples, cucumbers, pears, cherries and almond) are higher than those for honey crops such as radishes, red clover, blueberries (Rucker et al., 2012). The rental fee of managed bees is rising with time, because of diseases and the increasing demand of hives for crop pollination due to the increase in the fraction of agriculture that depends on animal pollination (Aizen and Harder, 2009; Rucker et al., 2012). In-kind payment of honey to beekeepers is also practiced in some cases (Rucker et al., 2012).

As for hive density, it depends on the attractiveness of the crop to pollinators (Paranhos et al., 1998; Finta, 2004). Higher densities of hives are necessary for good pollination of crops whose flowers are not very attractive. It is really tricky to provide the precise number of hives required per area for good pollination of crops, because many recommendations are available in the literature for each crop. For avocado pollination, McGregor (1976) recommended two hives per ha; Williams (1994) indicated eight hives per ha; while Dixon (2006) recommended ten hives per ha. The number of hives to use per area for a given crop varies according to field and colony conditions. Hive density could be affected by availability of natural habitats near the crops and then on availability of wild pollinators (Klein et al., 2012; Bailey et al., 2014).

The strength of the colony should also be taken into account to determine the hive density
(Sanford and Ellis, 1992). Hive density also depends on varieties of a focal crop to be pollinated (Woodcock, 2012). The supply of sufficient hives is important to ensure good pollination of crops. But high densities of honey bees could be harmful to crop production since many flowers are pollinated leading to competition of ovules for the resources required for fruit or seed development (Lloyd, 1980). This competition could result in abortion of ovules, seeds and fruits and then reduce the production (Teixeira et al., 2006).

During the blooming period, the number of bee hives requested by growers is moved to the field by trucks and in the night generally. To avoid that they return to their initial location, bees are moved far from that location. Hives are introduced in farms when a sufficient blossom is available. Somerville (1999a, 1999b) recommended introducing hives into crops at 5\% blossom to avoid bees searching for other sources of nectar and pollen. Hives are spread evenly throughout the crop, or placed in groups in a large number if it is not possible to distribute them within the crop (Scott-Dupree et al., 1995, Goodwin, 2012). In the latter case, it is preferable to place hives close to the crop and downwind to allow flower scent to reach bees. Some orchardists place hives on bin trailers that are moved throughout the orchard during the flowering period (Larue and Norton, 1989). Colonies that are not forage on the focal crop could be replaced by new ones (Scott-Dupree et al., 1995). During their stay in fields and orchards, bees are fed with sugar syrup, pollen or pollen substitutes.

To increase pollination efficiency of managed honey bees, different methods are used to increase bee visits and pollen delivered to flowers. Managed bee visits on flowers are increased by spraying honey bee attractants or chemical attractants on crops. Many attractants of different compositions are marketed and their efficiency varies with crops (Ambrose et al., 1995; Patil et al., 2011; Jayaramappa et al., 2011). According to Delaplane et al. (2010), the best chemical 
attractants contain synthetic queen pheromone or components of Nasonov pheromone. Instead of using bee attractants, sugar syrup is sprayed on flowers (Scott-Dupree et al., 1995; Goodwin, 2012) or flowers of the crop are ground and steeped in the sugar syrup or put in the hive (Larue and Norton, 1989). Additionally, removing competing blooms within or surrounding the farm or orchard contributes to maintain bee activity on the crop. To improve the amount of pollen dispersed by managed bees, hive inserts are set into the hive entrance and filled with pollen of crop to be pollinated (Larue and Norton, 1989). When leaving the hive, bees pick up more pollen that will be dispersed on flowers.

For some crops such as apples, it is necessary to plant appropriate polliniser varieties throughout the commercial cultivar (Gupta, 2012). It is also possible to provide pollen to bees by placing flowering branches of pollinisers on the ground underneath the trees, in the trees close to flowers to be pollinated, in containers of water spread throughout the crop or grafting polliniser on commercial cultivars (Scott-Dupree et al., 1995; Gupta, 2012; Goodwin, 2012). Another way to improve the quantity of pollen collected by managed bees is to increase pollen foragers of the colony. This is done by increasing the brood to adult bee ratios, trapping pollen or stripping pollen from hives and feeding sugar syrup (Goodwin, 2012). However, for crops pollinated mainly by nectar foragers, bees can be feed with pollen to increase collection of nectar.

Managed honey bee colonies for crops pollination. Colonies of the honey bee, Apis mellifera, are used to pollinate several crops. This review identified 66 crops, which growers successfully pollinate using managed honey bees (Table 1). The most pollinated groups of crops include fruits such as oranges, mangoes, the kiwifruit $(34.85 \%)$ and vegetables such as cabbages, the ccucumber and tomatoes (30.30\%). They are followed by oilseeds crops such as the sunflower and the canola (10.61\%); forage plants such as clovers and the alfalfa $(6.06 \%)$; tree nuts such as the cashew and the ccoffee $(6.06 \%)$, herbs and spices such as the bitter weed and the lavender $(6.06 \%)$, pulses such as the runner bean and the field beans (4.55\%) and cereal grains such as the corn $(1.52 \%)$. Most of the crops identified depend to some extent (1 to 100\%) on pollinators. Crops like the cashew, the canola and durian depend highly (40 to $90 \%$ ) on the pollination services; while others like lychee, longan and cabbage have a little (0 to $10 \%$ ) dependence on pollinators (Klein et al., 2007). Managed honey bees pollination services improve fruit or crop production (apple, almond, pepper, watermelon, avocado, etc.) as well as seed production (carrot, onion, etc.) in greenhouses and on open fields. This confirms that honey bees, in general and especially managed colonies, contribute to human food security and nutrition directly (fruits, vegetables, nuts, pulses, oilseeds, spices) and indirectly (forage).

The use of managed bee colonies for pollination services has been reported for 22 countries distributed on the five continents (Table 2). The practice has been reported mainly in USA (31 crops), Australia (24 crops), Netherlands (22 crops) and United Kingdom (21 crops). In some countries such as Spain, Sweden, Germany and Japan, the practice has also been mentioned. It is noticeable that almost all countries where Apis mellifera colonies are used to perform crop pollination are developed countries as stated by Bahadur et al. (2015).

Globally, the use of honey bee colonies to pollinate crops is poorly developed in Africa ( 2 countries, 15 crops) and in South America ( 2 countries, 4 crops). In Africa, bee colonies are used to pollinate crops such as carrots, peaches, peppers, mangoes and apples in Tunisia and South Africa. The low use of Western honey bee colonies for crop pollination in Africa could be due to weak losses of wild pollinators in the continent because of a limited agricultural intensification 
TABLE 1. Crops pollinated with managed colonies of honey bee Apis mellifera

\begin{tabular}{|c|c|c|c|c|c|c|c|}
\hline Fruits & Oilseeds & Vegetables & Forage and fodder & Tree nuts & Pulses & Cereal grains & Herbs and spices \\
\hline $\begin{array}{l}\text { Oranges, mandarin, } \\
\text { tangerine, clementine }\end{array}$ & $\begin{array}{l}\text { Rape, canola, } \\
\text { swede }\end{array}$ & Carrots & Lucerne/ & Almonds & Coriander & Corn & Caraway \\
\hline Mango & Sunflower & Onion & alfalfa & Cashew & Field beans & & Lavender \\
\hline Apple & Sesame & Peppers & Clovers & Macadamia & Runner bean & & Phacelia \\
\hline Peaches and nectarines & Linseed & Asparagus & Vetch & Coffee & & & Bitter weed \\
\hline Pomegranate & Borage & $\begin{array}{l}\text { Cabbages, cauliflowers, } \\
\text { broccoli, kale }\end{array}$ & Sainfoin/ esparcette & & & & \\
\hline Pears/nashi & Meadowfoam & Cucumber & & & & & \\
\hline Plums and prunes & Mustard & Radish & & & & & \\
\hline Cherries & & Tomatoes & & & & & \\
\hline Avocado & & Watermelon & & & & & \\
\hline Kiwifruit & & Eggplant & & & & & \\
\hline Blueberry & & Turnips & & & & & \\
\hline Apricots & & Chicory & & & & & \\
\hline $\begin{array}{l}\text { Blackberry/ loganberry/ } \\
\text { brambleberry/raspberry }\end{array}$ & & Ginseng & & & & & \\
\hline Strawberry & & Parsley & & & & & \\
\hline Currants and gooseberries & Parsnip & & & & & & \\
\hline Cranberry & & Leek & & & & & \\
\hline Passion fruit & & Fennel & & & & & \\
\hline Lychee & & Melons and cantaloupes & & & & & \\
\hline Grape & & $\begin{array}{l}\text { Pumpkins squash, zucchini, } \\
\text { courgette }\end{array}$ & & & & & \\
\hline Longan & & Rocket/ & & & & & \\
\hline Rambutan & & arugula & & & & & \\
\hline Durian & & & & & & & \\
\hline Holly & & & & & & & \\
\hline
\end{tabular}


TABLE 2. Countries and number of use (crops) of managed honey bee colonies reported for the present study

\begin{tabular}{llllll}
\hline Continents & Africa & Asia & Europe & America & Oceania \\
\hline Countries & South Africa(13) & China(1) & France (19) & Canada(19) & Australia (24) \\
& Tunisia(2) & India(1) & Germany (1) & Brazil (3) & New Zealand (16) \\
& & Israel (2) & Netherlands(22) & Chile (1) & \\
& & Japan (1) & Norway (1) & USA (31) & \\
& Korea(6) & UK (21) & & \\
& Thailand (7) & Spain (NA) & & \\
& & Swede (NA) & & \\
& & Bulgaria (1) & & \\
\hline
\end{tabular}

NA: Crops' names are not available

(Vandame and Palacio, 2010; van der Valk et al., 2013).

Apart from South Africa (13 crops listed), the use of honey bee colonies for crop pollination, mainly the payments for pollination services are almost unknown in Africa (Bosselmann and Hansted, 2015). Similarly, poor use of managed bees for pollination of crops was reported for countries such as Brazil and Bulgaria, because growers were unaware of the importance of bees (Imperatriz Fonseca et al., 2006; Panchev et al., 2014).

In countries such as USA, Australia, Canada and New Zealand, the use of managed bees in pollination services is so well developed that companies and beekeepers specialised in providing these services to growers are developed. This practice is so prominent that in North America, the majority of managed honey bee colonies are used for crop pollination (The Heinz Center, 2013). Delivering pollination services generates significant incomes for many US professional beekeepers; while European beekeepers are rarely paid for such services (OPERA Research Centre, 2012).

To promote this technology in Africa, researches must be conducted in order to access the need of pollination service and then its profitability in the current African entomological fauna context. Positive results from investigations must be followed by sensitisation of farmers who are unaware of the importance of bees. Honeybee species occurring in the continent which are currently managed for honey production could be used for this purpose.

Limitations and challenges of the use of Apis mellifera colonies. The use of managed honey bees, Apis mellifera, for crop pollination is beneficial for crop production, growers and beekeepers. However, this practice has some limits and challenges to overcome. Thought the honey bee is the most used species for crop pollination, it is not a panacea for all pollination deficit problems. Apis mellifera is not the most effective pollinators of all crops (Stanghellini et al., 1998; Greenleaf and Kremen, 2006; Bispo dos Santos et al., 2009). Therefore, other managed bees such as bumble bees (Bombus spp.) or alfalfa leafcutting bees (Megachile rotundata) are preferably utilised for pollination of tomato and alfalfa respectively. Some wild insects, mainly assemblages of wild insects have been demonstrated to be more effective than honey bees in pollination of certain crops (Garibaldi et al., 2013). Then pollination services provided by wild bees cannot be fully replaced by the one delivered by managed honey bees. Besides, wild bees sometimes contribute to improve pollination efficiency of honey bees, by forcing them to move to many flowers (Greenleaf and Kremen, 2006) as resources are then shared.

The pollination efficiency of A. mellifera is also affected by climate conditions since the 
species was found to be less active on flowers than wild bumble bees and the Asian honey bee, Apis cerana at lower temperatures (Willmer et al., 1994; Li et al., 2012). In hard climate conditions (wet, cloudy, or cool), Western honey bees remain in their hives (Vaughan et al., 2015) and become difficult to use for pollination of off-season crops. Despite the aforementioned limitations, the Western honey bee is probably used for pollination of many crops because growers do not have any other commercial alternatives (Greenleaf and Kremen, 2006) and the majority of wild effective pollinators of these crops have not yet been domesticated. Nevertheless, some farm management practices providing nesting sites around farms or orchards are established and promoted to ensure the presence of wild pollinators in crops.

Introduction of the honey bee ( $A$. mellifera) in a crop could lead to competition with native pollinators for floral resources. For instance, honey bees lessened the availability of pollen and nectar of foraging sites, obliging other insects to forage elsewhere (Horskins and Turner, 1999; Gross, 2001). In another study, the presence of the honeybee, $A$. Mellifera, in pumpkin fields significantly reduced visits of Peponapis pruinosa, a pollinator of this crop (Artz et al., 2011). Furthermore, owing to their aggressive competitor behavior, honey bees robbed nests and honey of other honey bees like Apis cerana (Moritz et al., 2005).

Competition with the Western honey bee could affect the fitness of individuals and later the survival of populations of inferior insect species because their reproductive success can be reduced (Thomson, 2004; Elbgami et al., 2014). Goulson and Sparrow (2008) noticed that workers of four bumble bee species, coexisting in the same area with honey bees had smaller size. Similar results were reported on bumble bee queens and males close to a honey bee apiary in UK (Elbgami et al., 2014).

Evidence of the effect of A. mellifera on other insect populations was provided by Yang et al. (2011), who reported a decline of Apis cerana populations in some Asian countries after introduction of $A$. mellifera. In addition to insect pollinators, honey bees could decrease visits of other kind of pollinators (birds and bats) onto flowers by limiting floral resources (Beard, 2015). Consequently, the effect of honey bees on foraging behavior and population size of pollinators influenced the reproduction of some plant species and changed the structure of plant communities (Howlett and Donovan, 2010).

Another effect of the Western honey bee on wild pollinators is its implication in the spread of diseases and parasites. Pathogens originally hosted by honey bees have spilled over to other insect species in which they are more virulent. For example, introduction of the honey bee into Asia was followed by a rise in a pathogen agent, Acarapis woodi, which caused severe losses of $A$. cerana colonies in India and Pakistan (FAO, 2006). Pathogens affecting honey bees were also transmitted to other insect pollinators. This is the case of the deformed wing virus, which occurred in bumble bees and caused important damages (Genersch et al., 2006). Managed honey bee colonies could also be affected by diseases and parasites from wild pollinators. The Varroa mite (Varroa destructor), which jumped from Apis cerana to managed colonies of $A$. mellifera (Rosenkranz et al., 2010) leading to a dramatic decline of $A$. mellifera colonies worldwide, is probably a good example in this context. Apart from that, managed honey bees could also contribute to proliferation of weeds because the species was implicated in pollination of some weed species (Collevatti et al., 1998; Barthell et al., 2001).

Negative consequences of the Western honeybee introduction in a new area suggest that researches must be conducted to assess the effect of the western honeybees on wild pollinators in controlled conditions before introducing A. mellifera in an area. Several subspecies of the Western honeybee occur around the world and are used for honey production by local communities (Bradbear, 
2010). Subspecies naturally occurring in each area could be used to limit negative effects of this practice on the local biodiversity.

Beekeepers and growers are confronted with several problems hampering the use of honey bee hives for crop pollination. One of the most important concerns is diseases and parasites, which affect bee colonies, causing range decline in many parts of the world. The phenomenon of Colony Collapse Disorder (CCD) whose causes are still unknown, has decimated honey bee colonies in some countries (Cox-Foster and van Engelsdorp, 2009). Unfortunately, some control products (miticides and antibiotics) used to treat infections can increase honey bees' susceptibility to viruses (Locke et al., 2011).

Honey bee mortality due to queen failure and starvation is another problem that beekeepers must overcome to maintain their colonies healthy for pollination. These factors have contributed to large decline, i.e. a reduction by 26.5 and $49.5 \%$ of managed colonies in Europe and North America respectively (vanEngelsdorp and Meixner, 2010), where managed hive using for pollination is important. This situation could affect availability of bee colonies to satisfy the increasing demand of pollination services. Shortage of honey bee colonies has already been reported in some US states, obliging beekeepers to import bees from Australia (National Research Council; 2007).

Owing to the overuse of pesticides, some beekeepers are reluctant to rent their colonies for pollination in some countries (Partap, 1998; Benecke, 2007). Even if growers renting bee colonies may take precautions before spraying according to contractual arrangements, pesticides can be applied in the surrounding farms that could be visited by bees without any precautions.

Countries experiencing lack of sufficient pollination, where humans are utilised as pollinators such as in some African countries, should also improve knowledge of farmers on the importance of honey bees in crop production in order to promote the use of domestic honey bee colonies to perform pollination of crops effectively pollinated by A. mellifera. Adoption of this pollination method will reduce pollination inputs and help farmers to increase their productivity and incomes.

\section{CONCLUSION}

Managed colonies of the Western honey bee, Apis mellifera, contribute to world food security because of their utilisation for pollination of several crops. The fact that honey bee use for crop pollination is mainly practiced in developed countries, should guide developing countries in the conception of their agricultural development models. Some of them are already engaged in modernisation of their agriculture, destroying natural habitats and increasing agrochemical use. Considering the importance of managed colonies of Apis mellifera in crop production, and their decline during last decades, it is necessary to improve management practices of other managed pollinators or establish favorable habitats for native pollinators around farms and orchards. Diversification of pollinators will surely improve pollination of crop and secure the world against a rapid and unexpected drop of honey bee colonies.

\section{ACKNOWLEDGEMENT}

We thank Roland Holou for its useful comments and suggestions on the manuscript.

\section{REFERENCES}

Aidoo, K., Adzanyo, M., Weidinger, R. and Tandjiekpon, A. 2015. The economic benefits of integrating beekeeping into cashew farms in Ghana and Benin. Abstract book of the $44^{\text {th }}$ APIMONDIA International Apicultural Congress hold from $16^{\text {th }}$ to $19^{\text {th }}$ September 2015 at Daejeon in South Korea. 118pp.

Aizen, A.M. and Harder, D.L. 2009. The global stock of domesticated honey bees is 
growing slower than agricultural demand for pollination. Current Biology 19:1-4.

Allsopp, M. 2005. Commercial pollination of deciduous fruit. DFPT Research. 7p. www.hortgro-science.co.za/wp-content/ .../3._bee_pollination.pdf. (Accessed on 14 March 2016).

Anderson, R.H., Buys,B. and Johannsmeier, M.F. 1983. Beekeeping in South Africa. Department of Agriculture Bulletin 394: 1207.

Ambrose, J.T., Schultheis, J.R., Bambara, S.B. and Mangum, W. 1995. An evaluation of selected commercial bee attractants in the pollination of cucumbers and watermelons. American. Bee Journal 135: 267-272.

Artz, D., Hsu, C. and Nault, B. 2011. Influence of honey bee, Apis mellifera, hives and field size on foraging activity of native bee species in pumpkin fields. Environmental Entomology 40:1144-1158.

Bahadur, B., Rajam, M.V., Sahijram, L. and Krishnamurthy, K.V. 2015. Plant Biology and Biotechnology: Volume I: Plant Diversity, Organization, Function and Improvement. Springer, India. 827pp.

Bailey, S., Requier, F., Nusillard, B., Roberts, S., Potts, S. and Bouget, C. 2014. Distance from forest edge affects bee pollinators in oilseed rape ûelds. Ecology and Evolution 4(4):370-380.

Barbouche N. 2009. La filière apicole en Tunisie: situation, contraintes et perspectives. servagri.eu/attachments/ article/74/La\%20Filière\%20Apicole $\% 20$ en\%20Tunisie.pdf. (Accessed on 18 March 2016).

Batra, S.W.T. 1995. Bees and pollination in our changing environment. Apidologie 26(5): 361-370

Bauer, D.M. and Wing, I.S. 2010. Economic Consequences of pollinator declines: A synthesis. Northeastern Agricultural and Resource Economics Association annual meeting held in Atlantic City, New Jersey, June 13-15.
Barthell, J.F., Randall, J.M., Thorp, R.W. and Wenner, A.M. 2001. Promotion of seed set in yellow star-thistle by honey bees: Evidence of an invasive mutualism. Ecological Applications 11:1870-1883.

Beard, C. 2015. Honey bees (Apis mellifera) on public conservation lands: A risk analysis. New Zealand Department of Conservation. 21p. http://www.doc. govt.nz/Documents/science-and-technical/ honeybees-on-public-conservationlands.pdf

Benecke, F. 2007. Commercial beekeeping in Australia. Rural Industries Research and Development (RIRDC), Publication No 07/ 059. 37pp.

Bispo dos Santos, A., Roselino, A.C., Hrncir, M. and Bego, L.R. 2009. Pollination of tomatoes by the stingless bee Melipona quadrifasciata and the honey bee Apis mellifera (Hymenoptera, Apidae). Genetics and Molecular Research 8(2):751-757.

Blitzer, E., Gibbs, J., Park, M. and Danforth, B. 2016. Pollination services for apple are dependent on diverse wild bee communities. Agriculture, Ecosystems and Environment 221:1-7.

Bosch, J. and Kemp, W.P. 2001. How to manage the blue orchard bee as an orchard pollinator. Sustainable Agriculture Network. Handbook series book 5. 88pp. https:// www.sare.org/content/download/29728/ 413964/file/How_to_Manage_the_Blue_ Orchard_Bee.pdf

Bosselmann, A.S. and Hansted, L. 2015. Payments for pollination services: An unexplored opportunity for African beekeepers. Abstract book of the 44th APIMONDIA International Apicultural Congress held at Daejeon, Korea, September16-19, 2015.

Bradbear, N. 2010. Le rôle des abeilles dans le développement rural : Manuel sur la récolte, la transformation et la commercialisation des produits et services dérivés des abeilles. FAO. Produits forestiers non ligneux ${ }^{\circ} 19$. Rome, Italie. 238pp. 
Burgett, M. 1999. 1998 Pacific Northwest honey bee pollination survey. The Bee Line 24(4):1-5.

Cane, J.H. and Sipes, S. 2006. Characterizing floral specialization by bees: Analytical methods and a revised lexicon for oligolecty. pp. 99-122. In: Waser, N.M. and Ollerton J. (Eds.). Plant-pollinator interactions: from specialization to generalization. University of Chicago Press.

Champetier, A. 2010. The dynamics of pollination markets. Selected paper prepared for presentation at the Agricultural \& Applied Economics Association 2010 AAEA, CAES and WAEA Joint Annual Meeting, Denver, Colorado, July 25-27, 2010. 44p. http://ageconsearch.umn.edu/ bitstream/61813/2/Pollination MarketsChampetierAAEA.pdf. (Accessed on 14 March 2016).

Collevatti, R.G., Campos, L.O. and da Silva, A.F. 1998. Pollination ecology of the tropical weed Triumfetta semitriloba Jacq. (Tiliaceae), in the South-Eastern Brazil. Revista Brasileira de Biologia 58: 383-392.

Cox-Foster, D. and vanEngelsdorp, D. 2009. Solving the mystery of the disappearing bees. Scientific American 2009: Is this year of publication or Volume no.? 40-47.

Cresswell, J.E. 2011. A meta-analysis of experiments testing the effects of a neonicotinoid insecticide (imidacloprid) on honey bees. Ecotoxicology 20:149-57 Is this correct?.

Delaplane, K.S., Thomas, P.A. and McLaurin, W.J. 2010. Bee pollination of Georgia crop plants. University of Georgia cooperative extension cooperative extension, bulletin 1106. $15 \mathrm{pp}$.

Dixon, J. 2006. Avocado Pollination, Best practice guidelines. Avocado Industry Council Ltd. and Kiwifruit Pollination Association. 13pp.

duToit, A.P. 1988. Pollination ecology of commercial sunflower (Helianthus annuus L.) in South Africa with special reference to the honeybee (Apis mellifera L.). MSc
Thesis, University of Pretoria, South Africa.

Elbgami, T., Kunin, W., Hughes, O.W. and Biesmeijer, J.C. 2014. The effect of proximity to a honeybee apiary on bumblebee colony fitness, development, and performance. Apidologie 45:504-513.

FAO. 2006. Honey bee diseases and pests: a practical guide. Agricultural and food engineering technical report 4. Rome, Italy. $33 p p$.

FAO, 2008. Tools for conservation and use of pollination services initial survey of good pollination practices. Rome, Italy. 133pp.

Finta, K. 2004. Insect pollination of apple orchards. PhD thesis, University of West Hungary, Faculty of Agricultural and Food Science. 28pp.

Garibaldi, L.A., Muchhala, N., Motzke, I., Bravo-Monroy, L., Olschewski, R. and Klein, A.M. 2012. Services from PlantPollinator interactions in the Neotropics. Ecosystem Services From Agriculture and Agroforestry: Measurement and Payment. DOI: $\underline{10.4324 / 9781849775656}$

Garibaldi, L.A., Aizen, M.A., Klein, A.M., Cunningham, S. A., Harder, L. D. 2011. Global growth and stability of agricultural yield decrease with pollinator dependence. Proceedings of the National Academy of Sciences of the United States of America 108:5909-5914.

Garibaldi, L.A.I., Steffan-Dewenter, R. Winfree, M. A., Aizen, R. Bommarco, S.A. Cunningham, ..... Initials? 2013. Wild pollinators enhance fruit set of crops regardless of honey bee abundance. Science 339:1608-1611.

Genersch, E., Yue, C., Fries, I. and de Miranda, J.R. 2006. Detection of deformed wing virus, a honey bee viral pathogen, in bumble bees (Bombus terrestris and Bombus pascuorum) with wing deformities. Journal of Invertebrate Pathology 91: 61-63.

Goodwin, M. 2012. Pollination of Crops in Australia and New Zealand. Rural 
Industries Research and Development Corporation. 121pp.

Goulson, D., Lye, G. C. and Darvill B. 2008. Decline and conservation of bumble bees. Annual Review of Entomology 53:191208.

Goulson, D., Sparrow, K.R. 2008. Evidence for competition between honeybees and bumblebees; effects on bumblebee worker size. Journal of Insect Conservation 13: 177-181.

Greenleaf, S. and Kremen, C. 2006. Wild bees enhance honey bees'pollination of hybrid sunûower. Proceedings of the National Academy of Sciences 103 (37): 1389013895.

Gross, C.L. 2001. The effect of introduced honeybees on native bee visitation and fruitset in Dillwynia juniperina (Fabaceae) in a fragmented ecosystem. Biological Conservation 102: 89-95.

Gupta, J. K. 2012. Role of insect pollinators in production of temperate fruits. In: Saini, R. K., Sharma, S. K. and Kumar, Y. (Eds.), advances in bio-ecology and management of insect pollinators of crops. Centre of advanced faculty training, Departement of entomology-CCS Haryana agricultural university, pp. 96-100.

Horskins, K. and Turner, V. B. 1999. Resource use and foraging patterns of honeybees, Apis mellifera, and native insects on ûowers of Eucalyptus costata.Australian Journal of Ecology 24: 221-227.

Howlett, B. G. and Donovan, B. J. 2010. A review of New Zealand's deliberately introduced bee fauna: current status and potential impacts. New Zealand Entomologist 33, 92-101.

Imperatriz Fonseca L., Saraiva M. and De Jong D. 2006. Bees as pollinators in Brazil: assessing the status and suggesting best practices. 112 pp. www.webbee.org.br/ webbee123/publicacoes/bees_pollinators. pdf. (Accessed on 15 March 2016).

Jayaramappa, K.V., Pattabhiramaiah, M. and Bhargava, H.R. 2011. Influence of bee- attractants on yield paramaters of ridge gourd (Luffaa cutangula L.) (Cucurbitaceae). World Applied Science Journal 15: 457- 462.

Kevan, P.G. and Phillips T.P. 2001. The economic impacts of pollinator declines: an approach to assessing the consequences. Conservation Ecology 5 (1): 8.

Klatt, B.K., Holzschuh, A., Westphal, C., Clough, Y., Smit, I., Pawelzik, E. and Tscharntke, T. 2014. Bee pollination improves crop quality, shelf life and commercial value. Proceedings of the Royal Society B: 281: 20132440. http:// dx.doi.org/10.1098/rspb.2013.2440

Kleijn, D. and Raemakers, I. 2008. A retrospective analysis of pollen host plant use by stable and declining bumble bee species. Ecology 89: 1811-23.

Klein, A. M., Vaissiere, B., Cane, J. H., SteffanDewenter, I., Cunningham, S. A., Kremen, C. and Tscharntke, T. 2007. Importance of crop pollinators in changing landscapes for world crops. Proceedings of the Royal Society of London: Series B. Biological Sciences 274: 303-313.

Klein, A.M., Brittain, C., Hendrix, S.D., Thorp, R., Williams, N.M. and Kremen, C. 2012. Wild pollination services to California almond rely on semi natural habitat. Journal of Applied Ecology 49: 723-732.

Koetz, A.H. 2013. The Asian honey bee (Apis cerana) and its strains - with special focus on Apis cerana Java genotype. Department of Agriculture, Fisheries, and Forestry, State of Queensland, Australia. 58pp.

Kovács-Hostyánszki, A., Batáry, P. and Báldi, A. 2011. Local and landscape effects on bee communities of Hungarian winter cereal fields. Agricultural and Forest Entomology 13: 59-66.

Kumar, Y. 2012. Honey bees: Management as pollinators. pp.136-139. In: Saini, R.K., Sharma, S.K. and Kumar, Y. (Eds.). Advances in bio-ecology and management of insect pollinators of crops. Centre of advanced faculty training, Departement of 
entomology-CCS Haryana Agricultural University, India.

LaRue, J. H. and Norton, M. V. 1989. Chapter 9 Japanese Plum Pollination. pp. 49-55. In: LaRue, J. H. and Johnson, R.S. (Eds.). Peaches, plums, and necatrines: growing and handling for fresh market. University of California.

Laurino, D., Porporato, M., Patetta, A. and Manino, A. 2011. Toxicity of neonicotinoid insecticides to honey bees: Laboratory tests. Bulletin of Insectology 64(1):107113.

Le Conte, Y. and Navajas, M. 2008. Climate change: impact on honey bee populations and diseases. Revue Scientifique et Technique-Office International des Epizooties 27: 499-510.

Li, J., Qin, H., Wu, J., Sadd, B. M., Wang, X., Evans, J. D., Peng, W. and Chen, Y. 2012. The prevalence of parasites and pathogens in Asian Honeybees Apis cerana in China. PLoS ONE 7 (11):e47955. DOI:10.1371/journal.pone.0047955.

Lloyd, D. G. 1980. Sexual strategies in plants. An hypothesis of serial adjustement of maternal investment during one reproductive session. New Phytologist 86: 69-79.

Locke, B., Forsgren, E., Fries, I. and de Miranda, J. 2012. Acaricide treatment affects viral dynamics in Varroa destructorinfested honey bee colonies via both host physiology and mite control. Applied and Environmental Microbiology 78: 227-35.

Mann, N.A. 2015. Intensive berry production using greenhouses, substrates and hydroponics. Is this the way forward? A report for Nuffield farming Scholar. 64pp.

McGregor, S.E. 1976. Insect pollination of cultivated crop plants. Agriculture Handbook, United States Department of Agriculture, viii $+411 \mathrm{pp}$.

Melhim, A., Weersink, A., Daly, Z. and Bennett, B. 2010. Beekeeping in Canada: Honey and Pollination Outlook. CANPOLIN publication $6.57 \mathrm{pp}$.
Melin A., Rouget M., Midgley J. and Donaldson J. S. 2014. Pollination ecosystem services in South African agricultural systems. South African Journal of Science 110(11/ 12), Art. \#2014-0078, 9 pages. http:// dx.doi.org/10.1590/sajs.2014/20140078.

Miguel, I., Iriondo, M., Garnery, L., Sheppard, W. S. and Estonb, A. 2007. Gene flow within the M evolutionary lineage of Apis mellifera: role of the Pyrenees, isolation by distance and post-glacial re-colonization routes in Western Europe. Apidologie 38: 141-155.

Mishra, R.C. 1995. Honeybees and their management in India. Indian Council of Agricultural Research New Delhi, India. $168 \mathrm{pp}$.

Moritz, R. F. A., Haertel, S. and Neumann, P. 2005. Global invasions of the western honeybee (Apis mellifera) and the consequences for biodiversity. Ecoscience 12:289-301.

Morse, R. A. and Calderone, N. W. 2000. The value of honey bees as pollinators of U.S. crops in 2000. Bee Culture 128:1-31.

National Research Council. 2007. Status of Pollinators in North America. National Academies Press. Washington, D.C. 326pp.

Ndola P.B. 2015. Etat des lieux de la filiere apicole en République Démocratique du Congo et évaluation des capacités pollinisatrices des abeilles domestiques (Apis mellifera adansonii, L.) sur la culture de melon africain (Cucumeropsis mannii, Naudin) à Kisangani. Thèse de doctorat, l'Université de Liège-Gembloux AgroBioTech. 117pp.

OPERA Research Centre. 2012. Bee health in Europe - An Overview. 19pp.

Panchev, H., Georgiev, A., Vasileva, B. and Georgiev, M. 2014. Apiculture status focus on the cross-border regions: Sofia District and District of Montana. Bulgaria - Serbia IPA Cross-border Programme, CCI Number 2007CB16IPO006-2011-2-96. $137 \mathrm{pp}$. 
Paranhos, B.A.J, Walder, M.M. and Marchini, L.C. 1998. Densidade de colmeias de abelhas africanizadas, Apis mellifera 1. 1758 (Hymenoptera: Apidae), para polinizar maçã cv. Anna. Scientia Agricola 55: $355-$ 359.

Partap, U. 1998. Successful pollination of apples in Himachal Pradesh. Beekeeping and Development 48: 6-7.

Partap, U. 1999. Pollination management of mountain crops through beekeeping Trainers' Resource Book. International Centre for Integrated Mountain Development (ICIMOD) publication. $117 \mathrm{pp}$.

Partap, T. 2001. Mountain agriculture, marginal land and sustainable livelihoods: Challenges and opportunities. International Symposium on Mountain Agriculture in HKH Region held from 21 to 24 May 2001. ICIMOD, Kathmandu, Nepal.

Partap, U. and Ya, T. 2012. The human pollinators of fruit crops in Maoxian County, Sichuan, China, a case study of the failure of pollination services and farmers' adaptation strategies. Mountain Research and Development 32 (2): 176186.

Partap, U. 2003. Cash Crop Farming in the Himalayas: The importance of pollinator management and managed pollination. pp. 224-247. In: FAO (Eds.). Biodiversity and the ecosystem approach in agriculture, forestry and fisheries.

Patil, J.S., Mokat, R.B., Mupade, R.V. and Kamate, G.S. 2011. Role of bee attractants in pollination and productivity of onion (Allium cepa L.). Journal of Entomological Research 35: 127-131.

Paudel, Y., Mackereth, R., Hanley, R. and Qin, W. 2015. Honey bees (Apis mellifera L.) and pollination issues: Current status, impacts, and potential drivers of decline. Journal of Agricultural Science 7 (6):93109.
Pilatic, H. 2012. Pesticides and honey bees: State of the Science. Pesticide Action Network North America (PANNA). 27pp.

Plant Health Australia. 2013. Varroa mite preparedness of pollination dependent industries. 44pp. http://www.planthealth australia.com.au/wp-content/uploads/ 2014/03/Varroa-Mite-Preparedness-ofPollination-Dependent-IndustriesReport.pdf. (Accessed on 15 March 2016).

Potts, S., Biesmeijer, J., Kremen, C., Neumann, P., Schweiger, O. and Kunin, W. 2010. Global pollinator declines: trends, impacts and drivers. Trends in Ecology and Evolution 25(6) : 345-353. DOI:10.1016/ j.tree.2010.01.007

Pouvreau, A. 2004. Les insectes pollinisateurs. La bibliothèque du naturaliste. Delachaux and Niestlé, Paris, France. ISBN-10: 2603014749. 89pp.

Rader, R., James, R., Bartomeus, I. and Winfree, R. 2013. Native bees buffer the negative impact of climate warming on honey bee pollination of watermelon crops. Global Change Biology 19:3103-3110.

Rosenkranz, P., Aumeier, P., Ziegelmann, B. 2010. Biology and control of Varroa destructor. Journal of Invertebrate Pathology 103: S96eS119. DOI:10.1016/ j.jip.2009.07.016.

Rucker, R., Thurman, N. and Burgett, M. 2012. Honey bee pollination markets and the internalization of reciprocal benefits. American Journal of Agricultural Economics 94(4): 956-977.

Sabbahi, R., De Oliveira, D. and Marceau, J. 2005. Inûuence of honey bee (Hymenoptera: Apidae) density on the production of canola (Crucifera: Brassicacae). Journal of Economic Entomology 98: 367-372.

Sagili, R. and Burgett, M. 2011. Evaluating honey bee colonies for pollination. A guide for commercial growers and beekeepers. A Pacific Northwest Extension Publication. 
ý https://catalog.extension.oregonstate.edu/ pnw623 (accessed on 12 September 2016).

Sammataro, D. and Avitabile, A. 1988. The beekeeper's handbook. Ithaca, New York: Cornell University Press. 131pp.

Sanford, M.T. and Ellis, J. 1992. Beekeeping: Watermelon Pollination. Department of Entomology and Nematology, UF/IFAS Extension document ENY-154; http:// edis.ifas.ufl.edu (accessed on 12 September 2016).

Scott-Dupree, C., Winston, M., Hergert, G., Jay, S. C., Nelson, D., Gates, J., Termeer, B. and Otis, G. 1995. A guide to managing bees for crop pollination. Canadian Association of Professionals Apiculturists. Canadian Departement of Agriculture. Aylesford. 36pp.

Somerville, D. 1999a. Pollination of apples by honey bees. New South Wales Agriculture Agnote DAI/132. State of New South Wales. 4pp.

Somerville D. 1999b. Honey bees in cherry and plum pollination. New South Wales Agriculture Agnote DAI/126. State of New South Wales. 3pp.

Stanghellini, M.S., Ambrose, J.T. and Schultheis, J.R. 1998. Stigmatic pollen grain deposition by honey bees and bumble bees after single bee visits to pistillate watermelon flowers. HortScience 33:484484.

Stanghellini, S., Ambrose, J.T. and Schultheis, J.R. 1998. Using commercial bumble bee colonies as back up pollinators for honey bees to produce cucumbers and watermelon. Horttechnology 8(4):590-594.

Teixeira, S. de P., Pereira, R.A.S. and Ranga, N.T. 2006. Components of fecundity and abortion in a tropical tree, Dahlstedtia pentaphylla (Leguminosae). Brazilian Archives of Biology and Technology 49: 905-913.

Thapa, R.B. 2006. Honeybees and other insect pollinators of cultivated plants: A review. Journal of Institute of Agriculture and Animal Sciences 27:1-23.
The Heinz Center. 2013. Rhode Island Pollinators and Agriculture. Washington, DC. 46pp.

Thomson, D. 2004. Competitive interactions between the invasive European honey bee and native bumble bees. Ecology 85:458470.

Tsutsumi, L.H. and Oishi, D.E. 2010. Farm and forestry production and marketing profile for honey bees (Apis mellifera). pp. 1-29. In: Elevitch, C.R. (Ed.). Specialty crops for Pacific Island agroforestry. Permanent Agriculture Resources (PAR), Holualoa, Hawaii.

Vandame, R. and Palacio, M.A. 2010. Preserved honey bee health in Latin America: A fragile equilibrium due to lowintensity agriculture and beekeeping? Apidologie 41: 243-255.

van der Valk, H., Irene Koomen, I., Nocelli, R., Márcia de F. Ribeiro, M.F., Freitas, B., Carvalho, S., Kasina, J., Martins, D., Mutiso, M., Odhiambo, C., Kinuthia, W., Gikungu, M., Ngaruiya, P., Maina, G., Kipyab, P., Blacquière, T., van der Steen, J., Roessink, I., Wassenberg, J. and Gemmill-Herren, B. 2013. Aspects determining the risk of pesticides to wild bees: Risk profiles for focal crops on three continents. FAO. Pollination services for sustainable agriculture, field manuals. Rome, Italy. 67pp.

van Engelsdorp, D. and Meixner, M.D. 2010. A historical review of managed honey bee populations in Europe and the United States and the factors that may affect them. Journal of Invertebrate Pathology 103: S80-S95.

Vaughan, M., Hopwood, J., Lee-Mäder, E., Shepherd, M., Kremen, C., Stine, A. and Black, S. 2015. Farming for bees guidelines for providing native bee habitat on farms. The Xerces Society for Invertebrate Conservation. 76pp.

Velthuis, H.W. and Doorn, A. 2006. A century of advances in bumblebee domestication and the economic and environmental 
aspects of its commercialization for pollination. Apidologie 37: 421-451.

Waite, M.B. 1895. The pollination of pear flowers. U.S. Department of Agriculture, Vegetable Pathology Bulletin 5. 86pp.

Weber, E. 2012. Apis mellifera: The domestication and spread of European honey bees for agriculture in North America. University of Michigan Undergraduate Research Journal 9:20-23.

Williams, I.H. 1994. The dependence of crop production within the European Union on pollination by honey bees. Agricultural Zoology Reviews 6:229-257.

Willmer, P.G, Bataw, A.M. and Hughes, J.P. 1994. The superiority of bumblebees to honeybees as pollinators: Insect visits to raspberry flowers. Ecological Entomology 19:271-284.

Woodcock, T. 2012. Pollination in the agricultural landscape best management practices for crop pollination. Canadian Pollination Initiative (NSERCCANPOLIN), University of Guelph, Canada. 113pp.

Yang, M.-X., Tan, K., Radloff, S.E. and Hepburn, H.R. 2011. Interspecific interactions among Asian honeybees. pp. 445-472. In: Hepburn, H.R. and Radloff, S.E. (Eds.). Honeybees of Asia; SpringerVerlag Berlin: Heidelberg, Germany. 